\title{
A new genus of Late Ordovician-Early Silurian pentameride brachiopods and its phylogenetic relationships
}

\author{
Jisuo Jin and Leonid E. Popov \\ Acta Palaeontologica Polonica 53 (2), 2008: 221-236 doi:http://dx.doi.org/10.4202/app.2008.0205
}

Protanastrophia repanda gen. et sp. nov. is a reef-dwelling parastrophinid brachiopod in the Lower Silurian (uppermost Telychian) Attawapiskat Formation of the Hudson Bay region of Canada. It is characterized by a small, quasi-smooth shell with gentle anterior costae, a tendency towards an asymmetrical, sigmoidal anterior commissure, and widely separate, subparallel inner hinge plates. Protanastrophia first appeared in the marginal seas of Siberia (Altai, Mongolia) during the Late Ordovician, retaining the primitive character of discrete inner hinge plates in the superfamily Camerelloidea, and preferred a carbonate mound depositional environment. It survived the Late Ordovician mass extinction and subsequently spread to Baltica and Laurentia during Early Silurian (Llandovery) time. Superficially similar asymmetrical shells of Parastrophina portentosa occur in the Upper Ordovician carbonate mound facies of Kazakhstan but differ internally from the new genus in having a septum-supported septalium. Phylogenetic analysis indicates that, within the Camerelloidea, asymmetrical shells with a sigmoidal anterior commissure evolved in Protanastrophia repanda and Parastrophina portentosa independently during the Late Ordovician as a case of homoplasy. The two species belong to separate parastrophinid lineages that evolved in widely separate palaeogeographic regions.

Key words: Brachiopoda, Parastrophinidae, Ordovician, Silurian, Canada, Siberia

Jisuo Jin [jjin@uwo.ca], Department of Earth Sciences, The

University of Western Ontario, London, Ontario, Canada N6A 5B7;

Leonid E. Popov [leonid.popov@ museumwales.ac.uk], Department of Geology, National Museum of Wales, Cathays Park, Cardiff, CF10 3NP, UK.

This is an open-access article distributed under the terms of the Creative Commons Attribution License (for details please see creativecommons.org), which permits unrestricted use, distribution, and reproduction in any medium, provided the original author and source are credited. 
FoF Full text $(597.8 \mathrm{kB})$ 